\title{
Students' Attitudes to Paper Consumption in relation to Carbon Emissions and the Impact of Electronic Course Documents
}

Mubanga Kapuka, Riverine Zambia Limited; Overson Shumba, School of Mathematics and Natural Sciences, Copperbelt University, Kitwe, Zambia; and Wizaso Munthali, School of Mines and Mineral Resources, Copperbelt University, Kitwe, Zambia

\begin{abstract}
The purpose of this study was to assess the impact, in relation to carbon emissions, of electronic course document use and attitudes to paper consumption levels among third-and fifth-year environmental engineering students $(N=78)$ enrolled in two courses during the 2015/2016 academic year at the Copperbelt University in Kitwe, Zambia. Data were collected through an online survey, to which 40 students provided complete responses, as well as through semi-structured interviews and observations. Overall, $80 \%$ of the students in the sample reported that they read electronic course materials. They also indicated that they 'know a lot' about sustainable development, climate change, greenhouse gases and global warming, and agreed that efficient paper use is an important aspect of achieving sustainability. Importantly, the study found that the lecturer's mode of delivery of course materials influenced the students to develop responsible environmental behaviours such as reading and sharing e-course documents and reusing paper.
\end{abstract}

Keywords: Climate change, paper consumption, education for sustainable development, higher education.

\section{Introduction}

The increase in global carbon emissions due to human activities such as deforestation and the burning of fossil fuel has become an issue of worldwide concern. As a result, many organisations and institutions, including universities, are striving to increase their environmental performance and responsibility. This includes efforts to reduce their carbon emissions, promote sustainability and combat climate change (IFL, 2016; IPCC, 2007; PBL, 2016; UNFCCC, 2007). In general, factoring sustainability in higher-education institutions focuses on greening the different aspects of campus activities in order to reduce carbon emissions, for example by reducing paper consumption (Robin, Potter \& Yarrow, 2002; Robin, Potter \& Yarrow, 2008). Paper is widely used in academia (EPN, 2015). Its production, consumption and disposal are known to have significant impacts on the environment - deforestation, high water consumption (in plantations), water pollution (during production), and carbon emissions, among others (Conservatree, 2015; Counsell \& Allwood, 2007; WWF, 2016). 
Reducing paper consumption on a global scale is important in lowering carbon emissions and, in turn, mitigating climate change. The Copperbelt University can make a small but important contribution in this regard by reducing its paper consumption, which would possibly also influence its students to adopt responsible environmental behaviours. To engender change in students, lecturers' actions must be consistent with the type of behaviour change they wish to encourage, such as utilising technology or methods in their teaching that benefit the environment (Lozano et al., 2011; Stir, 2006).

The Copperbelt University, which was established in 1987 and is located in Kitwe in the Copperbelt Province, is Zambia's second-largest public university. In its 2014-2018 Strategic Plan, the university has committed itself to supporting environmental sustainability (CBU, 2014). It has since initiated various projects such as tree-planting, an online admissions system, and a student portal for course registration and for accessing course materials.

A study at the Copperbelt University to assess the university's paper consumption over a period of five years (2010-2014) found that a significant amount of A4 paper was consumed for both academic and administrative purposes (Mwanza, 2014). Paper was the main mode of information dissemination and it was found that students used a lot of paper when printing or photocopying course materials. This contributed substantially to the university's carbon footprint (Mwanza, 2014). However, with the coming of the digital age, the use of e-documents (an electronic version of a printed document that can be read on a computer or a handheld device) has become prevalent, especially among university students (Falc, 2013; Hannon, 2008; Hobsons, 2010; McKiel, 2011). A number of researchers argue that replacing paper with its electronic equivalent can reduce paper consumption and its associated carbon emissions (Chowdhury, 2012; Counsell \& Allwood, 2007; Hannon, 2008; Hekkert, Reek, Worrell \& Turkenburg, 2002; Iqbal \& Ahmed, 2015; Tenhunen \& Penttinen, 2010).

The purpose of the present study was to assess the impact, in relation to carbon emissions, of electronic course document use and students' attitudes to paper consumption levels in two environmental engineering courses during the 2015/2016 academic year.

\section{Literature Review}

Trees, paper, carbon emissions and climate change

Forests provide the Earth's climate with critical stability through carbon storage. The process of photosynthesis enables trees to absorb carbon dioxide, a greenhouse gas, and offset its effect on the atmosphere (EDF, 2016). Globally, indigenous forests are either used directly for paper production or are cleared to make way for plantations in which pine and other trees are grown for paper production. Such plantations use large amounts of water, destroy indigenous ecosystems and, after harvesting, leave behind denuded areas unless replanted. Over 900 million planted trees are consumed for paper each year (EPN, 2015) and the world's annual pulp and paper production is around 400 million tons a year (WWF, 2016).

Approximately 36 billion tonnes of carbon emissions are generated globally from fossilfuel and other industrial processes (PBL, 2016), and paper and pulp production is a large consumer of energy. Some three billion tonnes of global carbon dioxide $\left(\mathrm{CO}_{2}\right)$ emissions 
are the result of deforestation (UCS, 2013), while tropical forests absorb 1.4 billion metric tonnes of carbon dioxide out of a total global absorption of 2.5 billion (Buis, 2014). During the production of paper from pulp, more water is used and the emissions and discharge from paper mills typically contain high levels of pollution. Every paper consumer is connected through the supply chain to the land where trees are harvested and processed to make paper (Gagliardi, 2007) - and, if fossil-fuel energy consumption and the resulting $\mathrm{CO}_{2}$ emissions associated with paper manufacture and transportation are added, the connection to climate change becomes even more apparent.

Over the last four decades, scientists have presented evidence that the rising concentration of carbon emissions has been driving changes in the Earth's climate patterns, resulting in catastrophic weather events in the form of floods in increased number and intensity, heatwaves and droughts. This poses a threat to human survival and sustainability (IPCC, 2007; NPCC, 2016). Zambia, like many other African countries, experiences climate-related hazards such as floods and droughts, which have adversely affected water availability, food security, energy supply, and the livelihoods of communities (NPCC, 2016).

\section{Sustainability and climate change awareness in universities}

A sustainable university is a whole or a part that addresses, is involved with and promotes, on a regional or a global level, the minimisation of negative environmental, economic, societal and health effects generated in the use of resources in order thereby to fulfil its functions of teaching, research, outreach, and partnership with society (Zhang, 2011). Environmental sustainability has become a priority for many tertiary institutions and different initiatives have been formulated through declarations so as to foster sustainabledevelopment guidelines on how to incorporate sustainability into the university system (Adomßent, Fischer, Godemann, Otte, Rieckmann, Timm \& Herzig, 2014; Lozano et al., 2011; Robin et al., 2002; UNESCO, 2009).

Lozano et al. (2011) identified some of the factors that contribute to resistance on the part of universities to engage with sustainability. These factors include: lack of awareness concerning sustainable development; the insecurity of lecturers and threats to academic credibility; overcrowded curricula; lack of support; views that sustainable development has little or no relevance in certain study disciplines; and uncertainty regarding the effort required to incorporate sustainable development into curricula. Universities that promote sustainability have been shown to be ones that have rethought their missions and have streamlined their research programmes and lifestyles on campus (Adomßent et al., 2014).

The Copperbelt University has conducted various studies aimed at understanding the university's carbon footprint as formed by different aspects such as water, refrigerants and paper (Mapulanga, 2013; Mulebeka, 2013; Mwanza, 2014). These studies have stressed the importance of education for disseminating climate change information, as well as education's central role in understanding, mitigating and adapting to climate change (UNESCO, 2009). For example, a survey of students in two hostels at the Copperbelt University designed to assess their awareness of climate change found that they had some awareness of climate change but very little knowledge of the carbon footprint of paper consumption (Mwanza, 2014). It 
would seem, from this, that they required more information. Researchers have also shown that awareness of climate change among students is influenced by access to information, by media coverage of the issue, by advocacy, and by the level of environmental concern (Carr, 2015; Christensen \& Knezek, 2015; Ojomo, Elliott, Amjad \& Bartram, 2015). At the Copperbelt University, it was therefore important to explore the awareness and attitudes of students regarding climate change. Bello (2015) showed the importance of this in a case study exploring students' green computing attitudes. In the present study, an online survey was designed to determing environmental engineering students' awareness and practices with reference to paper consumption and electronic course resources.

\section{Electronic and print course document use in universities}

The digital revolution has allowed documents to be accessed electronically. This is achieved using portable devices such as laptops, tablets and smartphones, which is a viable way of reducing carbon emissions and the costs incurred when printing or photocopying documents (Chowdhury, 2012; Counsell \& Allwood, 2007; Iqbal \& Ahmed, 2015; Tenhunen \& Penttinen, 2010). Around the world, universities that have shifted their academic activities and processes online have recorded good results in reducing costs (CSU, 2015; Hobsons, 2010; OrgSync, 2014). For instance, within one year of implementing such a project, Lamar University in the United States of America (USA) had a 51.2\% reduction in copier machine usage and printing costs (OrgSync, 2014).

In 2011, a survey was conducted on e-book penetration and use in academic libraries in the USA. The survey showed that nearly half of the students preferred using e-resources to print, with 30\% sometimes preferring them, and only 20\% always preferring print (McKiel, 2011). Other surveys on e-book use showed that 53\% (Ebrary, 2008) and 71\% (Lenares, 2012) of student respondents reported having used an e-book. However, one major constraint in reducing paper consumption is that some lecturers provide print course documents. Lecturers may even reject electronically submitted assignments, preferring assignments to be submitted as double-spaced or single-sided hard copies (Smyth, Fredeen \& Booth, 2010).

\section{Purpose of the Study}

The purpose of the present study was to explore students' attitudes to paper consumption levels, their awareness of climate change, and the impact of electronic course documents. The study involved third- and fifth-year environmental engineering students at the Copperbelt University who were enrolled for courses delivered electronically by their lecturers. The following research questions were explored in the study:

- What is the impact of electronic course document use among third- and fifth-year environmental engineering students enrolled in two courses: Solid Waste Management (EN 340) and Principles of Toxicology (EN 510)?

- What are the students' attitudes to paper consumption levels in relation to carbon emissions?

- How aware are students of the link between paper consumption and climate change? 


\section{Theoretical Framework}

Answering the aforementioned research questions is important in the light of what we know from Albert Bandura's (1977) social-learning theory and from the results of studies that explore the application of tenets of the theory of planned behaviour, which refines the reasoned action theory (Ajzen \& Fishbein, 1980; Bandura, 1977; Njaura, 2013). Bandura's theory stresses learning by observing and modelling what others do. The theory of planned behaviour explains environmentally responsible behaviour as a result of environmentally friendly behavioural intentions. In turn, environmentally friendly behavioural intentions are influenced by pro-environment attitudes, the social pressure to act, and perceived behavioural control. The theory of planned behaviour informed a study designed to examine the gap between the environmental attitudes and the actual behaviour of young people. In this study, it was found that the relationship between their behaviour and intentions was substantially stronger than the relationship between their behaviour and attitudes (Njaura, 2013). Theories such as these are relevant to the present study. It is expected that the behaviour of a role model - in this case, the course lecturer - in using, or demanding the use of, e-course documents will influence the learners' behaviour and encourage them to use e-documents as well, resulting in a reduction in paper consumption. Further, the students' attitudes would be expected to influence whether or not they develop intentions or actually act in ways to reduce paper consumption by adopting e-documents. This, in turn, would probably be influenced by how aware they are of paper consumption contributing to carbon emissions on a global scale, thereby causing climate change. The present study, in a modest way, raises awareness of one important course of action that a university can embark on, and of the appropriate attitudes which it can encourage, in order to reduce its carbon footprint, while simultaneously reducing operating costs resulting from course delivery. At the same time, the study is informed by an understanding that the adoption of environmentally responsible behaviour is not a simple process but includes the development of knowledge, attitudes and a locus-of-control belief, as well as the development of intentions to act among students and their lecturers. The relationship between the action of introducing e-documents and the awareness of the impacts of paper on global climate change can also work in multiple directions.

\section{Methodology}

A qualitative case study approach was used to investigate the impact, in relation to carbon emissions, of electronic course document use and attitudes to paper consumption levels among third- and fifth-year environmental engineering students. The number of students in each class was 33 and $45(N=78)$ during the 2015/2016 academic year. Yin (2009) defines a case study as an in-depth exploration of a particular context, such as a classroom or a group of individuals, which allows for the collection of extensive qualitative data employing multiple sources of data such as surveys, interviews and observations (Yin, 2009).

The rationale for selecting third- and fifth-year environmental engineering students as the study population was twofold. Firstly, the sample met the research criteria for a case study 
because the lecturers taking the two courses were committed to delivering the course content electronically. Secondly, the student researcher involved in the present study was taking one of the courses. As an 'insider', the student researcher was thus able to undertake in-depth exploration of the issues via interviews or observations.

\section{Online questionnaire}

With a view to cost-effectiveness, maximum convenience and the reduction of paper consumption, a self-administered online survey was designed. The semi-structured questionnaire was created on the SurveyMonkey platform. It consisted of two parts: students' attitudes to paper consumption and electronic course document usage; and awareness of climate change concepts. The questions were designed to explore the students' attitudes and were based on a three-point Likert scale ranging from 'Agree' to 'Disagree', with additional open-ended questions/responses. The survey also took less than 20 minutes to complete. Three faculty members validated the items for the survey. A pilot survey was administered to fourth-year environmental engineering students to check for clarity, relevance of the items for the purpose, and the accuracy of statements in the survey. The suggestions and comments provided regarding the survey helped to improve the final survey that was sent to 65 participants in January 2016. A total of 47 responses were received, of which 40 were complete responses.

\section{Interviews and observations}

After completion of the survey, semi-structured, one-to-one interviews were conducted using an interview schedule with seven open-ended questions in order to gain valuable and complete information regarding students' printing habits, their use of electronic documents and their awareness of the carbon footprint of paper. During the interviews, the students described their attitudes concerning electronic and paper course documents, their printing habits and the factors that enabled or constrained sustainable paper usage. This data was corroborated using observation data in respect of all the students' printing and electronic document use behaviour during the research period.

\section{Data collection and analysis}

The survey results were filtered for completeness of response and the data trends were then analysed. The desired sample size was $\mathrm{N}=78$, and 65 survey e-mails were returned. The response rate was thus $73.8 \%(n=47)$, of which $85.1 \%(n=40)$ were complete responses and $14.9 \%(\mathrm{n}=7)$ were partial responses. Verbal and email follow-up measures were put in place. Unfortunately, the indefinite closure of the 2015/2016 academic year affected the student response rate. The results for all closed-ended survey questions were summarised and analysed automatically in SurveyMonkey as charts, data tables and basic statistics.

Data was also gathered through observation and interviews. A case study with multiple data sources allows for assessing complex phenomena by considering the interrelationships among the data from the different sources (Yin, 2009). Interview responses were organised into categories and themes in line with the structured questions in order to interpret areas that were common and had similarities or contrasting views, and were then triangulated with data drawn from observations. 


\section{Findings and Discussion}

Observation, interview and survey findings indicating the students' self-reported attitudes to paper consumption and electronic course documents and their awareness of climate change, are now presented and discussed.

\section{Part 1: Students' attitudes to paper consumption and electronic course document usage}

\section{A4 paper consumption}

Students were asked to indicate the approximate amount of paper they had used to print course materials for the two courses. Figure 1 shows the percentage breakdown of the responses for the items in the survey. The results show that only $40 \%(\mathrm{n}=18)$ of the students used less than 100 sheets of paper, while $60 \%(n=27)$ used more than 100 sheets. Interview and observation data in respect of the students' paper consumption revealed that students did not accumulate a lot of paper in the two courses, compared with other courses for which they were enrolled. We hypothesise that the lecturer's mode of delivery of course materials influenced the students to reduce their paper consumption in line with the lecturer's observed actions (Bandura, 1977; Bandura, 1986)

\section{Preferred mode of viewing course materials}

The students were asked about their preferred mode of reading course materials and the results in Figure 2 show that 36\% $(\mathrm{n}=17)$ preferred electronic course documents, $34 \%(\mathrm{n}=16)$ preferred print documents, and 30\% $(\mathrm{n}=14)$ preferred both electronic and print documents. During the interviews, students gave various reasons in support of their preferred mode. Those preferring electronic documents argued that e-documents save paper and money and prevent the accumulation of large amounts of paper in their rooms. These students also expressed an intention to act - they believed that their actions were beneficial and contributed to reducing paper consumption and its associated emissions. Conversely, students who preferred print indicated that they concentrated more and felt more engaged when reading a print document.

\section{Factors affecting preference}

The main factor affecting the students' preferred mode of viewing course materials was the ease with which they were able to obtain or share documents. As shown in Figure 3, 58\% $(n=26)$ of the students considered the ease with which documents could be shared or obtained an important factor, followed by portability $(53 \%)(n=24)$. Another $7 \%(n=3)$ commented that electronic documents do not cost anything and reduce paper consumption substantially. In interviews, however, the majority of the students alluded to the fact that electronic course documents are easy to share and do not cost anything, unlike printed course documents that come at a price. Furthermore, students were observed sharing e-course documents using email, WhatsApp and portable drives. With regard to portability, students expressed varying views, with some asserting that carrying one print article is more convenient than carrying a laptop, while others said e-course documents are convenient because a large number of documents can be carried on a portable device such as a laptop or tablet when compared with printed textbooks. 
Figure 1. Students' number of A4 sheets consumption $(n=45)$ (percentage responses)

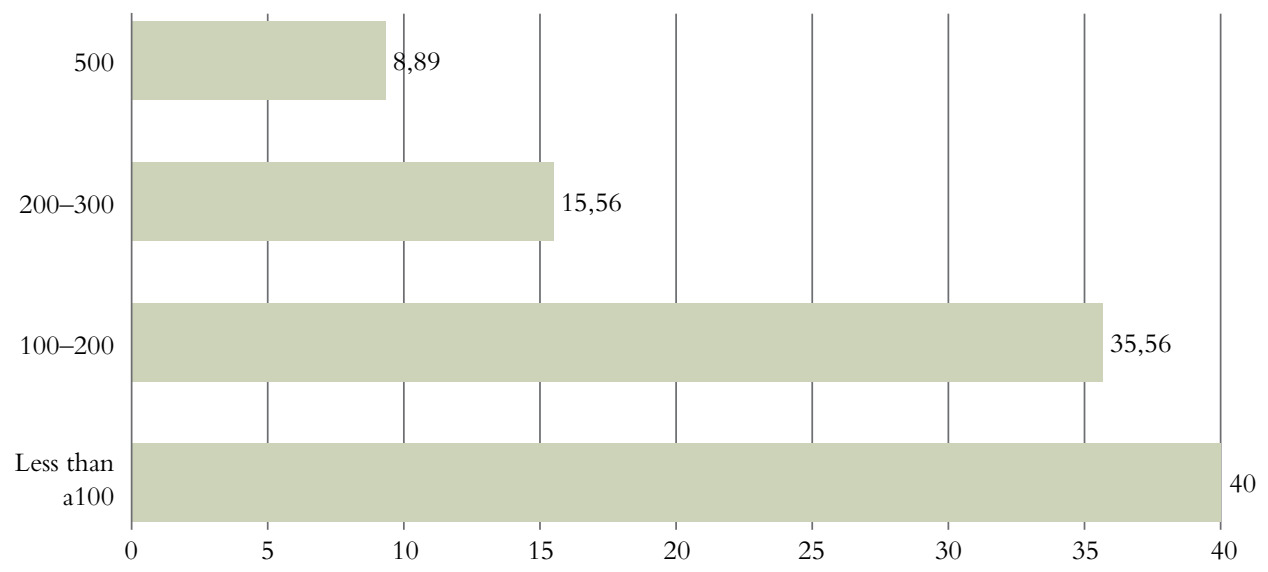

Figure 2. Preferred mode in respect of course materials $(n=47)$ (percentage responses)

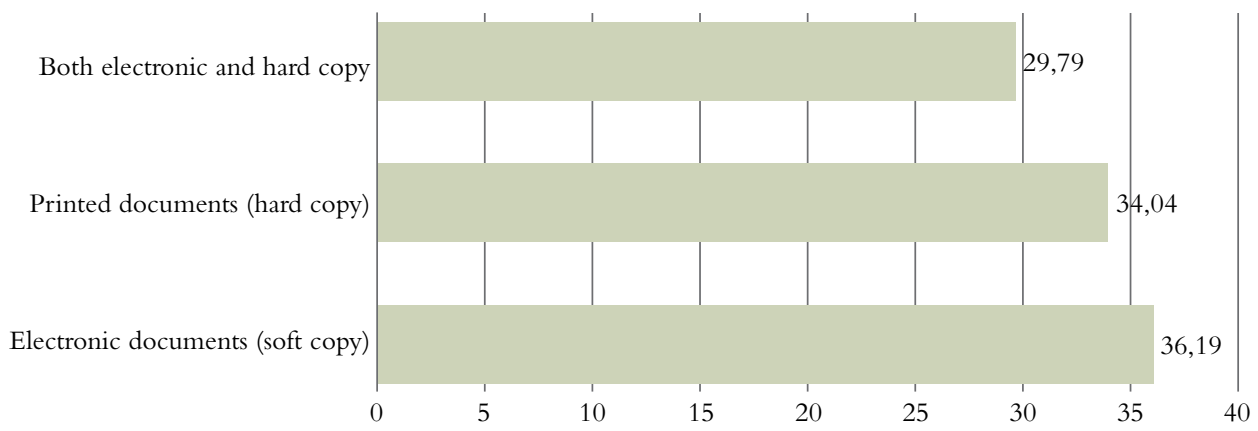

Figure 3. Factors affecting students' preferences $(n=45)$ (percentage responses)

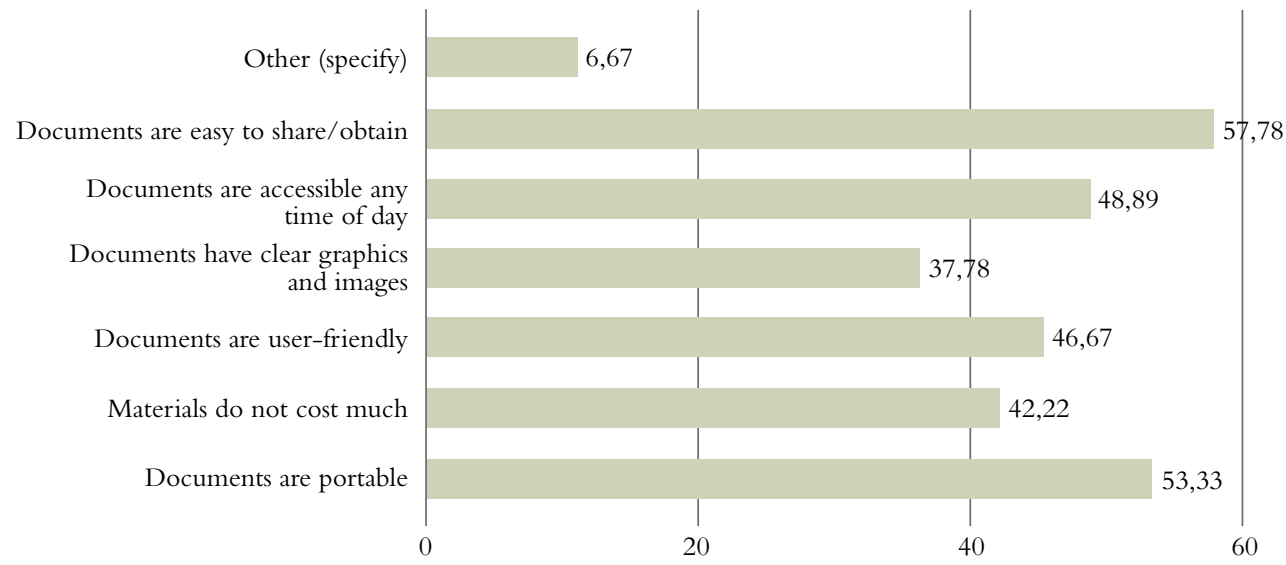




\section{Students' electronic course document use and printing habits}

With regard to students' printing behaviours and their attitudes to electronic course documents, between 78 and $80 \%$ of them indicated that they read course materials electronically. Of special note is that only a small percentage of the respondents (between 8 and 15\%) printed out parts or all the electronic course materials in order to read them. The observed positive attitude to reading e-documents may be attributed to increased ownership of laptop computers and to the electronic mode of delivery of course documents used by the lecturers.

Single-sided (simplex) printing was the most frequently used method of printing among students, with $61 \%$ of them reporting that they always used it. An examination of the printed course documents also showed that the majority of students' printed documents were printed single-sided. Most of the printers owned by the students did not have the automatic duplex (double-sided printing) function, while some students said it was not their concern whether duplex printing was used.

Figure 4. Students' electronic document use and printing habits $(n=46)$ (percentage responses)

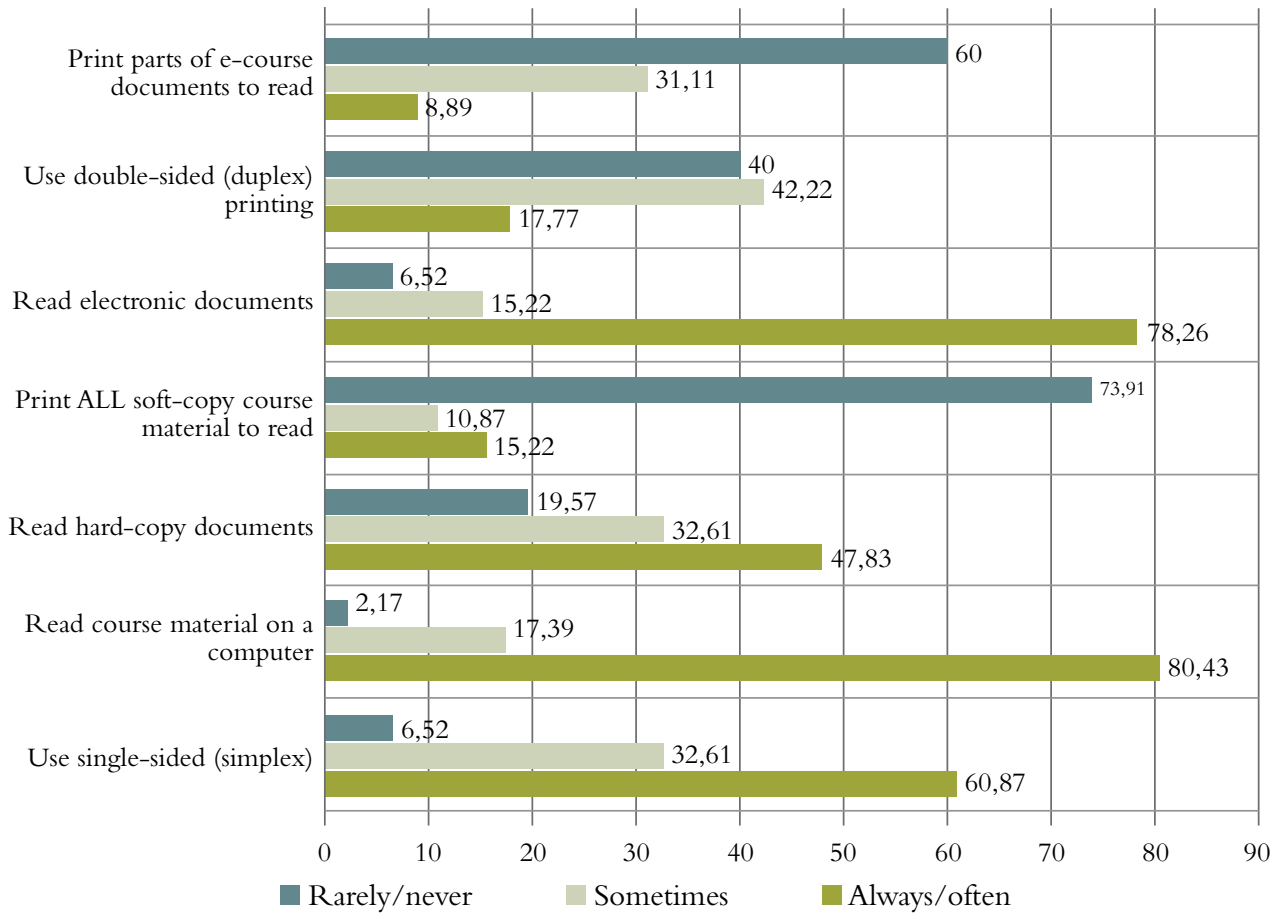

\section{Part 2: Students' knowledge and awareness of the carbon footprint of paper and of climate change concepts}

\section{Awareness of climate change and related concepts}

When students were asked about their awareness and knowledge of climate change concepts, over $70 \%$ of them indicated that they knew a lot about the concepts of greenhouse gases, 
global warming, climate change, carbon sinks and sustainable development. In contrast to the high levels of awareness of the concepts of greenhouse gases, carbon footprint and climate change, relatively few (29\% and 36\%) reported knowing a lot about the concepts of a paperless and green campus, respectively. During the interviews, students admitted that they were not knowledgeable about the concepts of a paperless and green campus, while others said they had heard about them but did not know what they entailed. Therefore, there were notable knowledge gaps regarding the concepts of a paperless and green campus. An openended question in the survey that asked students to comment on the link between paper manufacturing and use, on the one hand, and any of the concepts detailed in Figure 5, on the other, showed that over $60 \%$ of them were able to relate paper manufacturing and use to climate change. Some remarked that unsustainable paper consumption contributes to deforestation, which, in turn, leads to climate change due to an increase in greenhouse gases, thus hindering sustainable development. One student commented that the use of more electronic devices could help the university become green and paperless, as this would assist in bringing about a reduction in greenhouse gases resulting from paper consumption.

Figure 5. Students' awareness of climate change $(n=35)$ (percentage responses)

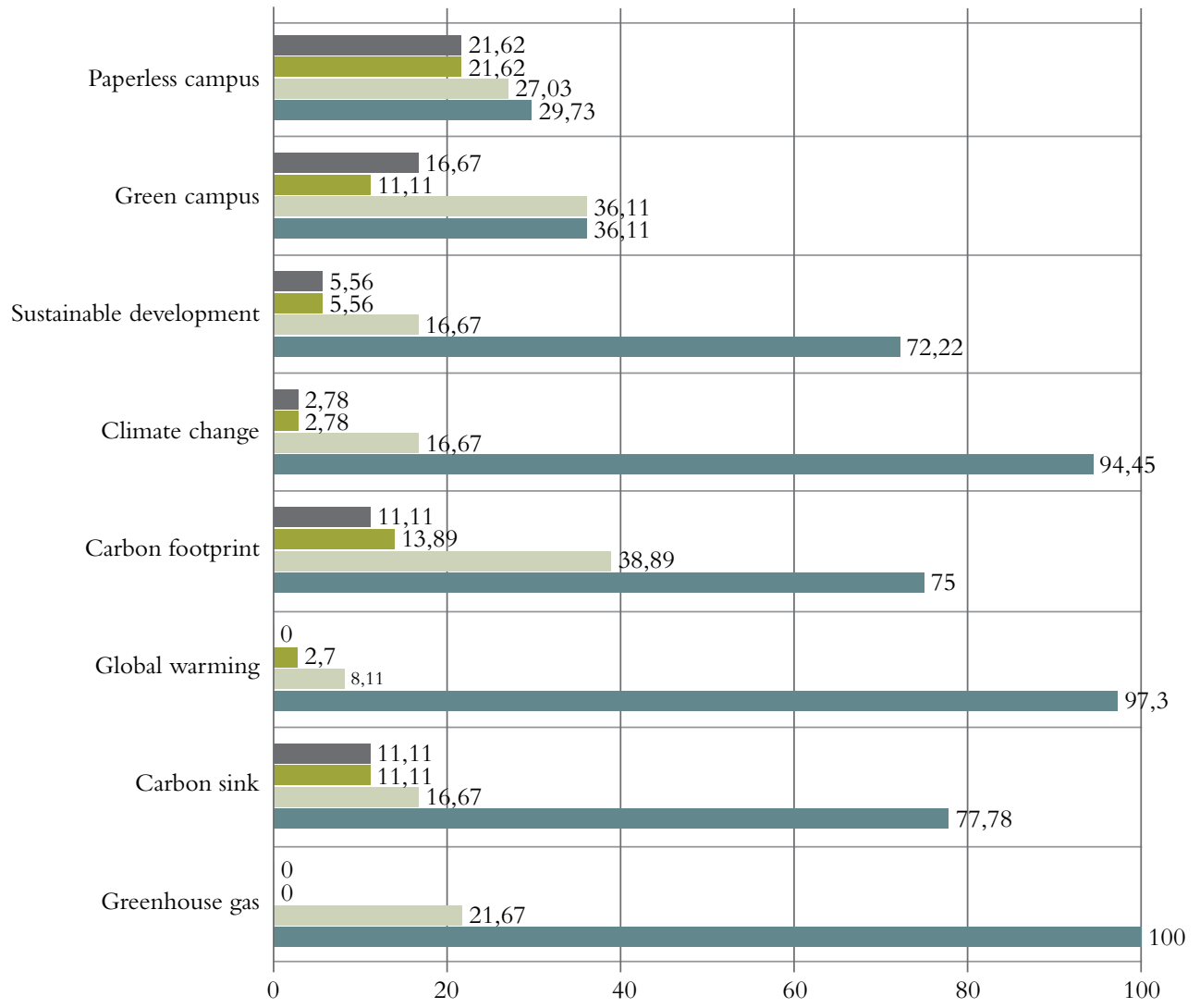

Know nothing about it $\square$ Heard something about it $\square$ Know little about it $\square$ Know a lot about it 
Awareness of the carbon footprint of paper

Almost all the students who answered questions on this were aware of the carbon footprint of paper. All 36 students who responded concerning this aspect knew a lot about the carbon footprint of paper and that efficient paper use is an important aspect of achieving sustainability (see Figure 6). Interviewee data suggests that the carbon footprint of the paper manufacturing industry was well understood. Students remarked that the planting of trees and the recycling of paper could also help to offset the carbon emissions associated with paper. The surveyed students therefore had a high awareness of climate change and of paper's carbon footprint. One could argue that this knowledge enabled them to reduce their paper consumption.

Figure 6. Awareness of the carbon footprint of paper $(n=36)$ (percentage responses)

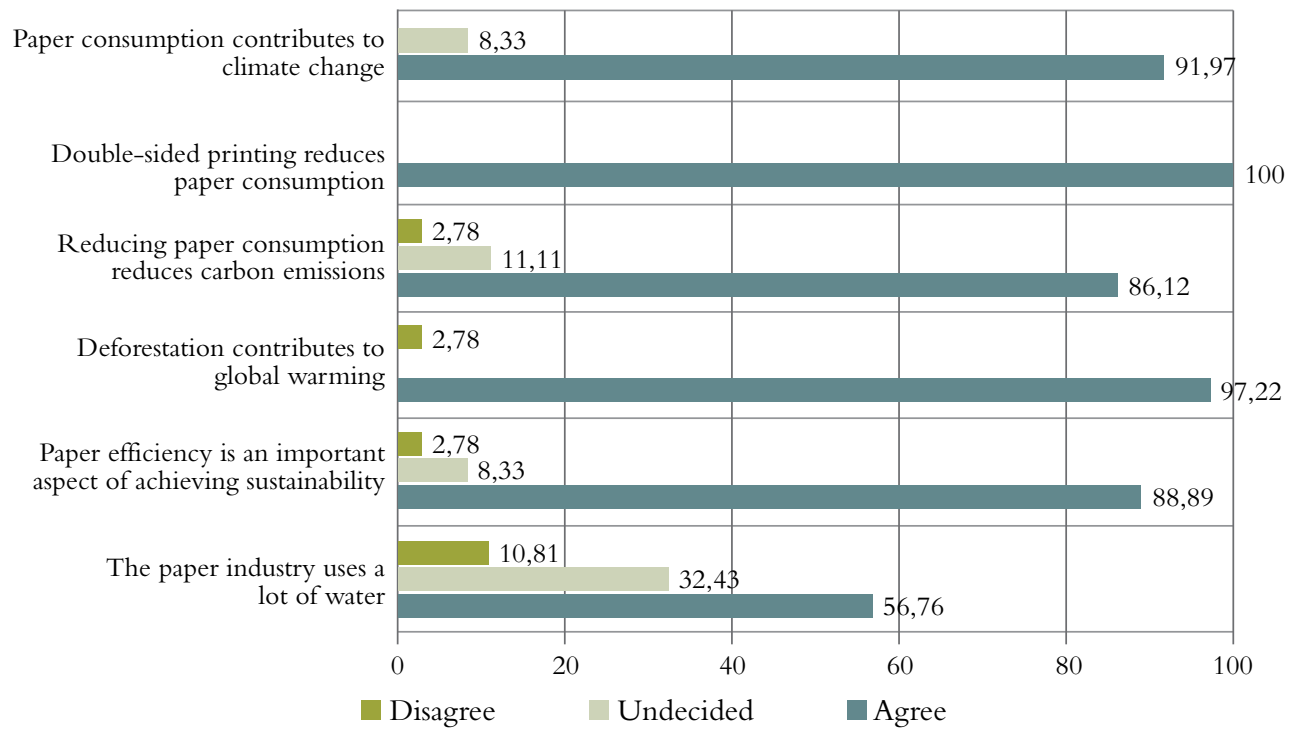

Students' sustainable paper use practices

When asked to indicate which of the sustainable paper use practices listed in the survey they applied, between $61 \%(n=22)$ and $100 \%(n=37)$ of the respondents indicated resorting to the sustainable paper use practices as shown in Figure 7. Interview and observation data confirmed that students employed most of the sustainable paper use practices described in the survey question, except that of duplex printing - despite being aware that duplex (double-sided) printing reduces paper consumption. Utilising both sides of a sheet of paper reduces the amount of paper consumed by half (Counsell \& Allwood, 2007) and seems to be the easiest solution for achieving reduced paper consumption. However, such printing is not popular among students because not all students' printers have the automatic duplex function. Nevertheless, it should be borne in mind that the manual method is time-consuming and that the cost of simplex or duplex printing is the same (Mwanza, 2014).

This would suggest that, despite high levels of awareness of climate change-related issues and an ability to link climate change and sustainability to paper consumption, this understanding 
may not always feature in students' paper consumption behaviour. Instead, factors like cost and convenience may, in some instances, be more important in shaping their consumption behaviour.

Figure 7. Students' sustainable paper use practices $(\mathrm{n}=35)$ (percentage responses)

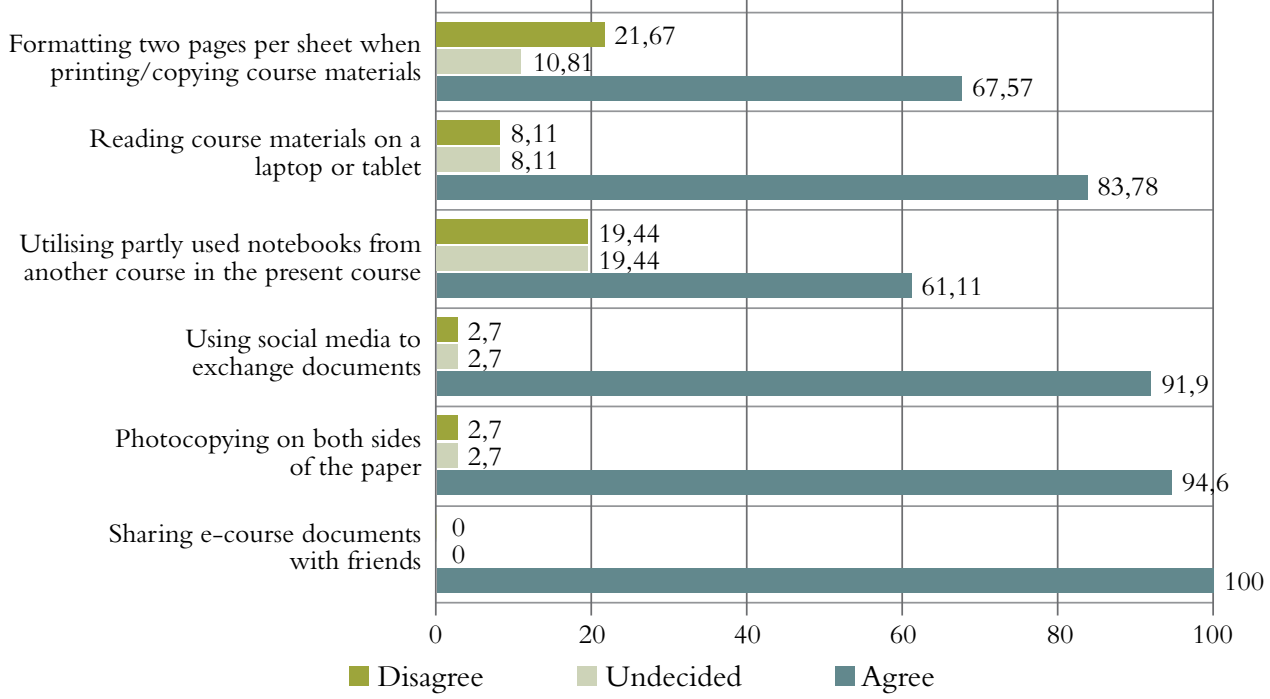

\section{Conclusions and Recommendations}

Overall, the majority of the students in the sample displayed environmentally responsible behaviours such as printing fewer documents, reusing paper, and reading and sharing electronic course documents. The students themselves attributed their reduced paper use in the two courses to reading electronic course documents and to reduced printing. To engender change in students' attitudes to paper consumption, lecturers must be consistent in exemplifying the type of behaviour change they wish to promote, such as the use of electronic course documents, and should demonstrate a belief in students' capacity to promote changes in their environment, for example by printing less and using e-course documents more often. This would be in line with the social- and behaviour-change theories informing the present study (Ajzen \& Fishbein, 1980; Bandura, 1977; Hungerford \& Volk, 1990).

With the rising cost of paper and printed textbooks, the use of electronic documents offers academia a cost-effective and efficient way of disseminating, accessing and viewing information. It can reduce the costs associated with purchasing paper and address environmental problems such as carbon emissions and waste-paper management (Counsell \& Allwood, 2007; Hannon, 2008; Iqbal \& Ahmed, 2015). However, a major constraint in reducing paper consumption is the fact that some lecturers provide hard-copy course documents and reject electronically submitted assignments, preferring instead to have assignments submitted in the form of double-spaced or single-sided hard copies (Smyth et al., 2010). Such an approach may be sending mixed messages to students. 


\section{Notes on the Contributors}

Mubanga Kapuka holds a bachelors degree in Environmental Engineering from the Copperbelt University, Zambia. His research interests are environmental management, climate change, and sustainability. He is a member of the Zambia Network of Environmental Educators and an associate at Riverine Zambia Limited, a multidisciplinary consultancy firm.

Professor Overson Shumba has multidisciplinary research interests in education for sustainable development (ESD), chemical education and teacher education. He is a member of the Reference Group for the UNESCO-SARUA flagship programme on the Global Action Programme (GAP), Sustainability Starts with Teachers.

Wizaso Munthali is an environmental expert who has worked in national environmental regulation and the environmental sector for 13 years. She is currently in the Environmental Engineering Department of the Copperbelt University, Zambia.

\section{References}

Adomßent, M., Fischer, D., Godemann, J., Otte, I., Rieckmann, M., Timm, J-M. \& Herzig, C. (2014). Emerging areas in research on higher education for sustainable development: Management education, sustainable consumption and perspectives from Central and Eastern Europe. Journal of Cleaner Production, 62, 1-7.

Ajzen, I. \& Fishbein, M. (1980). Understanding attitudes and predicting social behaviour. Englewood Cliffs, N.J.: Prentice Hall.

Bandura, A. (1977). Social learning theory. Englewood Cliffs, NJ: Prentice Hall.

Bandura, A. (1986). Social foundations of thought and action: A social cognitive theory. Englewood Cliffs, NJ.: Prentice Hall.

Bello, A. (2015). Assessing university students' attitude toward green computing practices. International Conference on Future Computational Technologies, Singapore.

Buis, A. (2014). NASA. http://www.nasa.gov/earthrightnow, visited 13 June 2016.

Carr, P. (2015). Climate change awareness amongst secondary level students and teachers in a Dar es Salaam university college of education (DUCE) affiliated school in urban Tanzania. Ireland: Trinity College Dublin/University College Dublin.

CBU. (2014). The Copperbelt University Strategic Plan 2014-2018. Kitwe: The Copperbelt University.

Chowdhury, G. (2012). How digital information services can reduce greenhouse gas emissions. Emerald Insight, 36(4), 489-506.

Christensen, R. \& Knezek, G. (2015). The climate change attitude survey: Measuring middle school student beliefs and intentions to enact positive environmental change. International Journal of Environmental \& Science Education, 10(5), 773-788.

Conservatree. (2015). Trees into paper. http://conservatree.org/learn/EnviroIssues/TreeStats. shtml, viewed 6 August 2015. 
Counsell, T. \& Allwood, J.M. (2007). Reducing climate change gas emissions by cutting out stages in the life cycle of office paper. Resources, Conservation and Recycling, 49(4), 340-352.

CSU. (2015). Cleveland State University paperless campus. http://www urban.csuohio.edu, viewed 3 December 2015.

Ebrary. (2008). Global students' ebook usage. s.l.: s.n.

EDF. (2016). Environmental Defence Fund. https://www.edf.org/climate/redd, visited 2 August 2017.

EPN. (2015). The Environmental Paper Network. http://c.environmentalpaper.org/baseline, visited 22 September 2015.

Falc, E. (2013). An assessment of college students' attitudes towards using an online e-textbook. Interdisciplinary Journal of E-Learning and Learning Objects, 9.

Gagliardi, M.A. (2007). The paper consumer's guide to climate change: How to reduce greenhouse gases with smarter paper choices. Metafore \& Gagliardi Group.

GRZ. (2016). National climate change policy. Lusaka: Government of the Republic of Zambia.

Hannon, C. (2008). E-texts in the classroom: E-text readers designed for use in higher education will reduce textbook pricing and address environmental concerns. Educause Quarterly, 1(11), 12-13.

Hekkert, M., Reek, J., Worrell, W. \& Turkenburg, W. (2002). The impact of material efficient end-use technologies on paper use and carbon emissions. Resources, Conservation and Recycling, 36(3), 241-266.

Hobsons. (2010). Pushing paper out the door: Making paperless admissions a campus reality. Hobsons.

Hungerford, H. \& Volk, T. (1990). Changing learner behaviour through environmental education. Journal of Environmental Education, 21(3), 8-21.

IFL. (2016). Intact forest landscapes. http://intactforests.org/, viewed 3 April 2016.

IPCC. (2007). Impacts, adaptation and vulnerability. Contribution of Working Group II to the Fourth Assessment Report. Intergovernmental Panel on Climate Change. Cambridge: Cambridge University Press.

Iqbal, H. \& Ahmed, F. (2015). Paperless campus:The real contribution towards a sustainable low carbon society. IOSR Journal of Environmental Science, Toxicology and Food Technology (IOSRJESTFT), 9(8), 10-17.

Lenares, D. (2012). E-book use and acceptance in an undergraduate institution. Massachuttes: Springer.

Lozano, R. et al. (2011). Declarations for sustainability in higher education: Becoming better leaders through university systems. Journal of Cleaner Production, 1-10.

Mapulanga, N. (2013). Assessing the carbon footprint of refrigerants at CBU. Kitwe: The Copperbet University.

McKiel, A. (2011). 2011 global e-book students' survey. Oregon: Western Oregon University.

Mulebeka, D. (2013). Assessment and quantification of economic losses of water leakages in CBU. Kitwe:The Copperbelt University.

Mwanza, P. (2014). Assessing the Copperbelt University students' paper consumption practices and attitudes towards associated carbon emission levels. Kitwe:The Copperbelt University.

Njaura, A. (2013). Using the theory of planned behaviour to investigate the determinants of environemental behaviour among youth. Environmental Research Engineering and Management, 1(63), 74-81.

NPCC. (2016). National policy on climate change. Lusaka: Ministry of National Development Planning. 
Ojomo, E., Elliott, M., Amjad, U. \& Bartram, J. (2015). Climate change preparedness: A knowledge and attitudes study in southern Nigeria. Environments, 2, 435-448.

OrgSync. (2014). Your campus engangement network. http://www.orgsync.com, visited 4 January 2016. PBL. (2016). Trends in global carbon dioxide emissions: 2016 report. The Hague: PBL Nertherlands Environmental Assessment Agency.

Robin, R., Potter, S. \& Yarrow, K. (2002). Factoring sustainability into the higher education product service. Journal of Sustainable Product Design, 2, 105-117.

Robin, R., Potter, S. \& Yarrow, K. (2008). Designing low carbon higher education systems: Environmental impacts of campus and distance learning systems. International Journal of Sustainability in Higher Education, 9, 116-130.

Smyth, S., Fredeen, A. \& Booth, L. (2010). Reducing solid waste in higher education: The first step towards 'greening' a university campus. Resources, Conservation and Recycling, 54, 1007-1016.

Stir, J. (2006). Restructuring teacher education for sustainability: Student involvement through a strengths model. Journal of Cleaner Production, 14(11), 830-836.

Tenhunen, M. \& Penttinen, E. (2010). Assessing the carbon footprint of paper vs. electronic invoicing. Associated Information Systems.

UCS. (2013). Union of Concerned Scientists. http://www.ucsusa.org/global_warming/ solutions/stop-deforestation/deforestation-global-warming-carbon-emissions.html\#. WZ11n42Qy02, visited 17 August 2017.

UNESCO. (2009). Learning to mitigate and adapt climate change. Paris: United Nations Educational, Scientific and Cultural Organization.

UNFCCC. (2007). Climate change: Impacts,vulnerabilities and adaptions in developing countries. United Nations Framework Convention for Climate Change.

WWF. (2016). World Wildlife Fund. http://wwf.panda.org/about_our_earth/deforestation/ forest_sector_transformation/pulp_and_paper/, visited 18 June 2017.

Yin, R.. (2009). Case study research design methods. CA:Thousand Oaks.

Zhang, N. (2011). Greening academia: Developing sustainable waste management at UK higher education institutions. Southhampton: University of Southhampton. 